\title{
Nilai-nilai Pendidikan Karakter Dalam Budaya Genteng Desa Mayong Kidul Jepara
}

\author{
Akhmad Iskhaq ${ }^{1}$, Ika Oktaviyanti ${ }^{2}$, dan Nur Fajrie ${ }^{3}$
}

PGSD Universitas Muria Kudus

Email: akhmad.iskhaq66@gmauil.com

\section{Info Artikel}

Sejarah Artikel:

Diserahkan: 25 Mei 2021

Direvisi: 19 Juni 2021

Disetujui: 28 Juni 2021

Keywords: culture, tile, charachter

\section{Abstract}

Culture is a system of society that includes a whole way of life of humans in groups in the form of physical and non-physical culture and is hereditary through a learning process so that it becomes part of life. The tile culture is a culture that is owned by the people of Mayong Kidul Jepara. Tile is a craft made of clay that is burned using high temperatures and used as a roof for buildings. In its manufacture, it is reflected in the character values that have been attached to the craftsmen community in the village of Mayong Kidul. In the current context, the character of children in Indonesia can be said to be lacking in morality. This can be seen from the news that has appeared in various media, one of which is juvenile delinquency. Character education has become a government program that aims to form moral individuals, but it seems that it has not been running perfectly. So it takes cooperation between education, society and family. This study aims to describe the values of character education in tile culture. This study uses a narrative qualitative method in presenting the research data. The process of collecting data through interviews, observations and field notes. The results show that in tile culture there are educational values in fostering character between discipline, cooperation, responsibility and honesty. Therefore it must be preserved so as not to be eroded by the times. 


\section{Akhmad Iskhaq \\ Nilai-Nilai Pendidikan Karakter Dalam Budaya Genteng Desa Mayongkidul Jepara \\ JURNAL PRASASTI ILMU Volume 1 Nomor 2 hlm. 34-41}

\section{PENDAHULUAN}

Negara Indonesia merupakan negara majemuk yang terdiri dari berbagai ragam budaya. Tepatnya budaya adalah suatu kata benda kolektif yang digunakan untuk mendefinisikan lingkungan atau ranah umat manusia yang mempunyai ontologi secara jelas dan terpisah dari lingkungan yang bersifat semata-mata fisik alamiah. Rondiyah, Wardani \& Saddhono (2017: 142) menyatakan Budaya berkembang dalam masyarakat sebagai wujud perilaku yang membentuk kebiasaan, dari kebiasaan itulah nilai dan norma-norma masyarakat terbentuk melalui budaya yang perlu diajarkan didalam pendidikan karakter.

Pembentukan karakter tidak semata-mata berasal dari pendidikan formal maupun non formal saja akan tetapi dapat diperoleh melalui jalur mana saja yang dirasa dapat memberikan pendidikan yang baik bagi dirinya salah satunya adalah pendidikan melalui budaya setempat yang berakar dari karya kreativitas masyarakat setempat.

Seperti halnya masyarakat Mayong Kidul, budaya genteng terintegrasi nilai-nilai karakter didalamnya. Kebiasaan masyarakat setempat yang mengedepankan kebersamaan dan kerjasama serta gotong royong dari anggota keluarga maupun masyarakat lainnya menjadikan mereka bersama dalam setiap waktu. Dengan adanya kerjasama tersebut aktivitas yang dijalani akan terasa lebih ringan.

Sehingga dengan kebiasaan-kebiasaan itulah karakter dapat terbentuk dengan apa yang dilakukan dalam kesehariannya. Salim, Salik \& Wekke (2018: 48) mengemukakan karakter adalah perilaku manusia yang berhubungan dengan allah SWT, diri sendiri sesama manusia, lingkungan dan kebangsaan yang terwujud dalam pikiran, sikap, perasaan perkataan dan perbuatan yang berdasarkan norma-norma agama, Tata krama, budaya dan adat istiadat.

Maka pembentukan karakter yang dilakukan masyarakat setempat melalui kebiasaan sehari-hari budaya mereka yang secara tidak langsung telah menginternalisasikan kepribadian mereka lewat kebiasaan sehari-hari. Rondiyah, Wardani \& Saddhono (2017: 142) pendidikan karakter merupakan proses pemberian tuntunan kepada individu untuk menjadi manusia seutuhnya berkarakter yang dimaknai sebagai pendidikan nilai budi pekerti, nilai moral dan watak yang bertujuan mengembangkan kemampuan individu dalam mengambil keputusan yang didasari oleh pemikiran yang matang dengan mempertimbangkan baik buruknya.

Namun Seiring perkembngan zaman, generasi muda sekarang rasa kepeduliannya semakin luntur terhadap budaya yang dimiliki. Padahal dalam sebuah budaya terkandung nilainilai luhur yang dapat diterapkan pada kehidupan dalam hubungannya dengan Tuhan Yang Maha Esa, sesama manusia, dan juga lingkungan. Kebudayaan menjadi sebuah keseluruhan dari hasil kreativitas manusia yang beragam.

Devianty (2017: 231) menyatakan kebudayaan merupakan sesuatu yang akan mempengaruhi tingkat pengetahuan, serta meliputi sistem ide atau sebuah gagasan yang ada dalam pikiran seorang manusia sehingga dalam kehidupan sehari-hari bersifat abstrak. Budiono (2010: 39) mengemukakan kebudayaan juga berupa fisik dan nonfisik yang mencakup seluruh sistem kehidupan manusia yang berupa gagasan dan rasa, tindakan, serta karya manusia dalam kehidupan masyarakat yang dijadikan miliknya melalui belajar. Jadi kebudayaan merupakan suatu keseluruhan cara hidup manusia dalam kelompoknya baik berupa fisik yang berwujud atau non fisik melalui proses belajar dan berkembang seiring berjalannya waktu.

Septiana (2018: 83) mengemukakan sistem mata pencaharian merupakan salah satu unsur budaya yang sangat penting dalam memenuhi hajat hidup manusia dan masyarakat, yaitu cara yang dilakukan sekelompok orang sebagai kegiatan sehari-hari untuk pemenuhan kehidupan, dan menjadi pokok penghidupan baginya.

Pada kehidupan masyarakat, nilai-nilai budaya dapat di integrasikan dan diturunkan dari generasi tua kepada generasi yang lebih muda melalui keluarga dan lingkungan masyarakat di sekitarnya. Masyarakat Mayong Kidul merupakan masyarakat yang mayoritas warganya 
berprofesi sebagai pengrajin genteng. Fenomena desa sentra kriya genteng di Mayong Kidul menunjukkan kerajinan ini merupakan produk ekonomi yang dimiliki masyarakat setempat dalam memenuhi dan menunjang kebutuhan sehari-hari. Selain produk ekonomi, genteng merupakan produk kebudayaan yang diteruskan secara turun-temurun oleh masyarakat setempat.

Hal ini dinyatkan oleh Budhi Ramdhani dari hasil wawancara yang menyatakan

"Kerajinan genteng ini adalah usuha turun-temurun dari orang tua, jadi seperti memeng itu pekerjaan yang dimiliki orang disini”.

Dari pernyataan narasumber bahwa kerajinan genteng ini merupakan usaha turuntemurun yang diwariskan kepada generasi berikutnya, sehingga profesi ini menjadi prioritas masyarakat di Mayong Kidul.

Purbasari \& Fajrie (2020: 90) mengemukakan bahwa budaya yang telah diterapkan dalam keluarga memunculkan interaksi dalam lingkungan masyarakat untuk mengembangkan ikon lokalitas yang berdampak pada kemajuan desa. Genteng merupakan bagian dari struktur bangunan yang digunakan sebagai atap yang berfungsi untuk melindungi dari segala kondisi cuaca alam. Hatmanto (2009: 8) menjelaskan genteng merupakan suatu struktur bangunan yang berfungsi sebagai penutup atap, terbuat dari campuran antara tanah liat dan bahan campuran lainnya seperti padas dan pasir, lalu dilumatkan dengan air sehingga mudah di cetak sesuai dengan bentuk yang dikehendaki kemudian dibakar hingga matang dan menjadi keras.

Namun dalam pembudayaannya sekarang, mengalami pergeseran yang fluktuatif dimana anak-anak didesa tersebut kurang peka terhadap kebudayaan yang dimiliki seiring perkembangan teknologi dan industri dari luar. Anak-anak didesa tersebut lebih mementingkan gadgetnya dan bermain bersama temannya. Melihat juga di sekitar daerah Mayong jepara mengalami bertambahnya industri pabrik asing seperti garmen, sepatu, otomotif dan yang lainya yang memungkinkan masyarakat beralih ke industri luar. Dengan demikian kebudayaan desa tersebut secara perlahan di abaikan oleh calon generasi penerusnya. Sehingga nilai-nilai budaya didalamnya tidak begitu diresapi dalam kehidupan sosial masyarakat. Selain itu pengrajin menganggap mereka hanya mencari uang untuk memenuhi kebutuhan sehari-hari dan tidak terfikirkan makna nilai didalamnnya.

Penelitian ini bertujuan untuk menggambarkan nilai-nilai karakter dalam budaya genteng yang merupakan nilai etos kerja masyarakat setempat dimana salah satunya masyarakat pengrajin menjujung tinggi kebersamaan dan kerjasama baik dengan anggota keluarga maupun pengrajin lainnya. Sehingga nilai tersebut dapat membentuk kepribadian seseorang di kehidupan sosial masyarakat khusunya anak SD yang harus ditanamkan karakter sejak dini agar menjadi pribadi bermoral dan memiliki karakter baik yang nantinya akan menjadi penerus bangsa yang besar dan berwibawa dimata dunia.

\section{METODE PENELITIAN}

Metode dalam penelitian ini menggunakan penelitian kualitatif dengan objek pengrajin genteng di dukuh panjunan desa Mayong Kidul, Kecamatan Mayong, Kabupaten Jepara yang dilaksanakan pada bulan Oktober 2020 - Maret 2021. Masyarakat desa tersebut mempunyai nilai kerja etos yang tinggi. Pendekatan dalam penelitian ini bersifat desktiptif naratif.

Moelong (2010: 7) pendekatan naratif adalah prosedur penelitian yang menghasilkan data deskriptif berupa kata-kata tertulis atau lain dari orang-orang dan perilaku yang di amati. Teknik pengumpulan data yang digunakan meliputi wawancara, observasi dan dokumentasi. Uji keabsahan data pada penelitian ini menggunakan teknik triangulasi. Triangulasi yang dilakukan dengan triangulasi teknik dan triangulasi sumber. Analisis data yang digunakan meliputi reduksi, penyajian dan penyimpulan data.

\section{HASIL DAN PEMBAHASAN}

Mayoritas Masyarakat Mayong Kidul merupakan pengrajin genteng. Kerajinan ini menjadi prioritas pekerjaan masyarakat di 


\section{Akhmad Iskhaq \\ Nilai-Nilai Pendidikan Karakter Dalam Budaya Genteng Desa Mayongkidul Jepara \\ JURNAL PRASASTI ILMU Volume 1 Nomor 2 hlm. 34-41}

wilayah Mayong Kidul. Masyarakat setempat memulai memproduksi genteng pada tahun 1960 . Pada saat itu proses produksi genteng menggunakan teknik manual yang di geprekgeprek dengan tangan sehingga membentuk genteng. Memasuki tahun 1980 mulai tercipta alat press sebagai alat memproduksi genteng. Adanya alat press tersebut masyarakat lebih mudah dalam memproduksi genteng, waktu yang di butuhkan lebif efektif dan dapat menghasilkan produk yang banyak dan berkualitas.

Seiring perkembangan waktu, kerajinan ini bertambah banyak peminatnya. Mulai dari kalangan muda sampai tua. Genteng merupakan pruduk ekonomi masyarakat Mayong Kidul yang terbuat dari tanah liat yang digunakan sebagai atap bangunan. Genteng mempunyai karakteristik yang keras setelah dibakar di suhu yang tinggi. Di masyarakat Mayong Kidul kerajinan ini menjadi pemandangan yang wajar di setiap sudut rumah. Hampir semua keluarga mempunyai gudang sebagai tempat produksi genteng yang digunakan sebagai sumber penghasilan.

Pada proses pembuatannya, genteng memerlukan waktu yang panjang sampai menjadi bahan jadi. Tahapanya yang cukup panjang memerlukan adanya kerja sama yang dibutuhkan antara anggota keluarga dan masyarakat. Dalam proses pembudayaannya keluarga pengrajin genteng maupun masyarakat telah mengenalkan kerajinan tersebut secara sadar mauapun tidak sadar kepada anak-anak didesa tersebut. Lingkungan desa yang mendukung menjadikan mereka bertemu setiap hari di lingkungan sekitarnya. Sehingga pemandangan ini menjadi pemandangan yang wajar di desa tersebut dan menjadikan anak mau tidak mau menyesuiakan diri dengan lingkungannya.

Proses pembuatan genteng mengandung nilai-nilai karakter yang di integrasikan di dalamnya. Nilai-nilai karakter yang tercermin dalam kerajinan genteng antara lain :

\section{A. Nilai Disiplin}

Masyarakat Mayong Kidul merupakan masyarakat penghasil genteng berkualitas dengan berbagai macam jenis genteng. Tentunya hal ini menjadi sumber penghasilan yang di andalkan sebagian besar masyarakat Mayong Kidul yang bergantung pada kerajinan tersebut. Kerajinan ini sudah ada sejak lama sekitar tahun 1960. Yang di awali dengan cara manual digeprek-digeprek menggunakan tangan, namun seiring berjalannya waktu kerajinan genteng mengalami perkembangan yang pesat. Terciptanya alat press manual yang digunakan dalam mencetak genteng. Dengan alat press ini pengrajin terbantu dalam produksinya selain mudah dioperasikannya, waktu yang dibutuhkan lebih efisien sehingga dapat menghasilkan genteng dalam jumlah yang lebih banyak. Dalam kesehariannya masyarakat Mayong Kidul mempunyai jiwa disiplin yang tinggi. Disiplin merupakan sikap taat dan patuh pada ketentuan atau peraturan yang ada baik peraturan dari jiwa seseorang itu sendiri maupun perarturan dari luar yang berlaku. Asyari, Erik \& Ahsin (2021: 38) mengemukakan disiplin merupakan perilaku tepat waktu dan taat dengan peraturan yang telah dibuat.

Hal ini ditunjukkan pada Setiap harinya masyarakat memulai aktivitas pekerjaanya dari jam 7 hingga sore pukul 4. Kebiasaan ini sudah melekat pada diri pengrajin, tujuannya bukan lain adalah agar menghasilkan genteng dengan jumlah yang banyak dikarenakan untuk memenuhi target produksi agar genteng cepat terkumpul dan bisa melakukan pengobongan (pembakaran) dengan secepat mungkin karena pengrajin bisa mendapatkan hasil penjualan yang nantinya akan digunakan untuk perputaran usaha dan kebutuhan keluarga. Seperti yang dikatakan Budhi Ramdhani dari hasil wawancara yang mengemukakan

"Biasanya pukul 7 saya sudah digudang sampai ba'da asar kira-kira jam 4”. Selain itu Bambang Sutrisno juga mengungkapkan hal yang sama

"Saya biasanya memulai pekerjaan pukul 7 sampai setengah 4".

Hal ini menunjukkan bahwa masyarakat pengrajin menerapkan kedisiplinan yang baik dalam dirinya. Sehingga jiwa kedisiplinan terbentuk secara alamiah melalui kebiasaan sehari-hari mereka. Selaras dengan Wicaksono 


\section{Akhmad Iskhaq \\ Nilai-Nilai Pendidikan Karakter Dalam Budaya Genteng Desa Mayongkidul Jepara \\ JURNAL PRASASTI ILMU Volume 1 Nomor 2 hlm. 34-41}

(2017: 191) yang menyatakan bahwa disiplin merupakan sikap mental yang dimiliki individu dan hakikatnya mencerminkan rasa ketaatan dan kepatuhan yang didukung oleh kesadaran dalam menjelaskan tugas dan kewajibannya untuk mencapai tugas tertentu.

Pada dasaranya pengrajin mempunyai kepatuhan yang dibuat oleh dirinya sendiri dan dilaksanakan menurut keyakinannya. Dengan disiplin pengrajin percaya akan menghasilkan genteng yang banyak dan lebih cepat ke tahap pembakaran dan penjualan sehingga dari hasil tersebut dapat mencukupi kebutuhan ekonomi keluarga dan perputaran usaha untuk kedepannya.

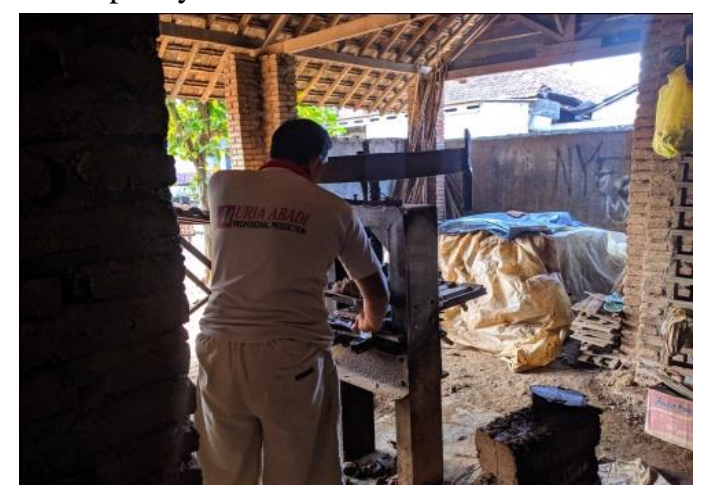

Gambar 1

Proses pengepressan genteng

Dengan disiplin yang baik memunculkan rasa tannggung jawab yang besar baik kepada diri sendiri dan orang lain juga. Ningrum, Ismaya \& Fajrie (2020: 105) menyatakan dengan adanya kedisiplinan yang tertanam pada diri seseorang melahirkan suatu bentuk sikap tanggung jawab baik pada individu itu sendiri maupun kepada orang lain.

\section{B. Nilai Kerjasama}

Pembuatan kerajinan genteng memerlukan waktu yang relatif panjang untuk menjadi genteng utuh dan berkualitas yang digunakan sebagai bagian dari struktur bangunan. Agar pekerjaan cepat selesai dan menghasilkan genteng yang banyak perlu adanya kerja sama antara orang per oreang atau kelompok lainnya. Rukiyati dkk (2014: 223) menjelaskan kerjasama merupakan suatu usaha bersama antara orang perorang atau kelompok untuk mencapai tujuan tertentu. Setiap langit terlihat biru dan matahari mulai muncul. Anggota keluarga bekerja sama mengeluarkan semua gentengnya yang ada digudang untuk di jemur dengan cara di japit atau dipikul yang nantinya akan ditata berdiri di tanah lapang di bawah terik matahari.

Penjemuran ini dilakukan selama 8 Jam sampai benar-benar kering. Setelah kering setiap anggota memainkan perannya kembali untuk mengambil genteng yang sudah kering untuk di tata di gobong.

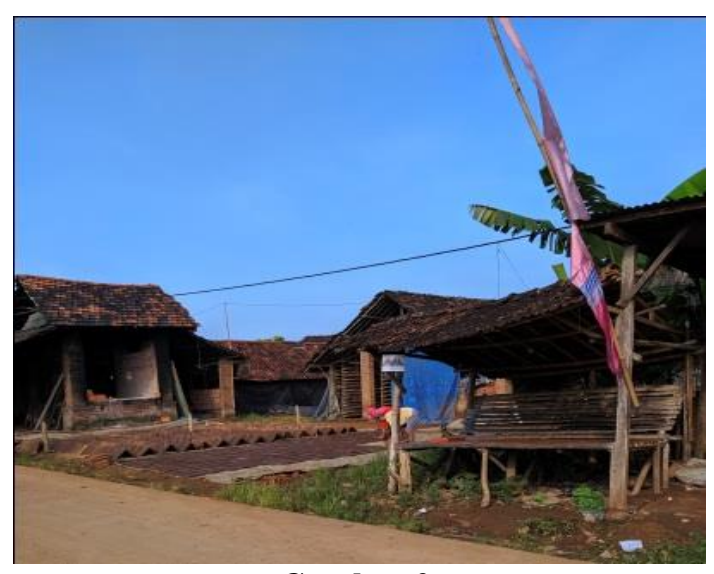

Gambar 2

Penjemuran genteng

Hal ini di ungkap narasumber Bambang Sutrisno yang menyatakan

"Yang pasti dalam bekerja ya harus bekerjasama ada yang ngepres, ada yang ngerik, ada yang menjemur".

Selain itu bentuk kerjasama juga diterapkan pada proses pembakaran seperti yang diungkap Miftakhus Salma

"Dalam proses pembakaran kan dibutuhkan 2 orang nah itu saling bekerja sama agar api menyala terus".

Adanya kerjasama ini dapat meringankan dan mempercepat produksi genteng sehingga tujuan yang di inginkan akan cepat terlaksana yakni tahap pembakaran dan penjualan. Hal ini senada dengan Listyani (2017) menyatakan kerjasama merupakan sikap penyelesaian dan pemecahan masalah yang di lakukan bersama-sama demi mencapai tujuan bersama. 


\section{Akhmad Iskhaq \\ Nilai-Nilai Pendidikan Karakter Dalam Budaya Genteng Desa Mayongkidul Jepara \\ JURNAL PRASASTI ILMU Volume 1 Nomor 2 hlm. 34-41}

\section{Nilai Tanggung Jawab}

Tanggung jawab menjadi nilai pendidikan karakter yang ada dalam masyarakat Mayong Kidul khususnya pengrajin genteng. Setiap pengrajin yang melakukan penghalusan tanah dan pembakaran bertanggung jawab terhadap pekerja yang lain. Pada proses ini biasannya pengrajin memerlukan bantuan dari tenaga pengrajin lainnya untuk melakukan proses penghalusan dan pembakaran.

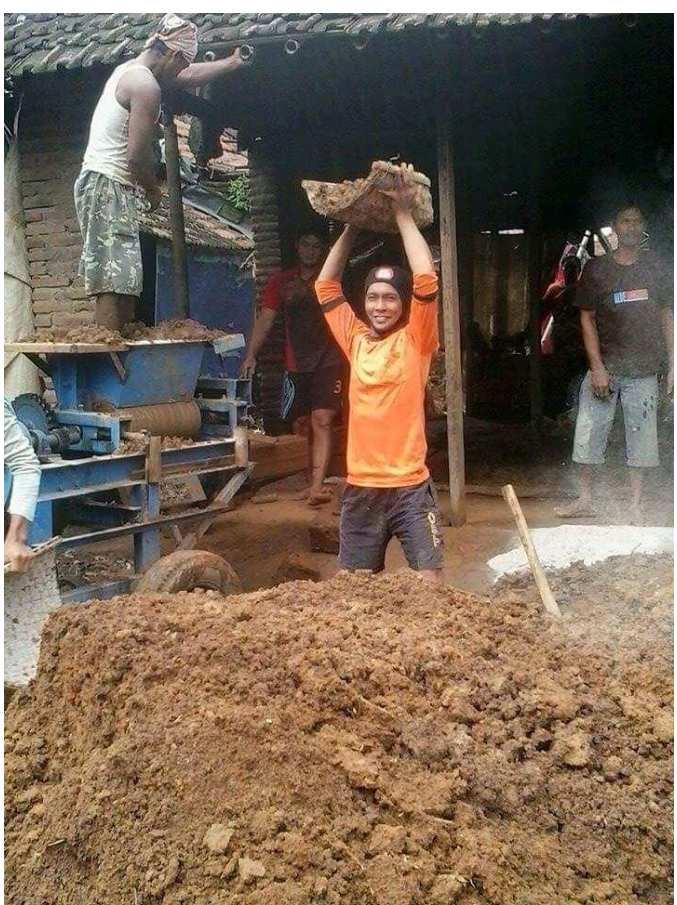

Gambar 3

Proses penghalusan tanah

Tahap penghalusan di perlukan tenaga sebanyak 5-6 orang yang bekerja sama memasukan tanah ke mesin molen. Sedangkan dalam proses pembakaran dibutuhkan tenaga kerja sebanyak 2 orang yang bertugas untuk menjaga agar api tetap hidup. Seperti yang diungkap narasumber Muhammad Fachri

"Ya tanggung jawab kepada pekerja lain. Misalkan pada pembakaran itu membutuhkan pekerja lain kita bertanggung jawab memberi makan, minum dan upah".

Hal ini juga diungkap oleh bapak Buono yang mengungkapkan
"Nilai-nilai yang muncul akibat membuat genteng adalah, disiplin dalam bekerja, tolong-menolong, jujur dan tanggung jawab kepada pekerja lain".

Proses pembakaran menggunakan grajen yang berasal dari serbukan kayu mebel, dengan cara grajen dicukil menggunakan odak atau potongan bambu sepanjang 2,5 meter ke mulut gobong. proses pembakaran ini dilakukan selama kurang lebih $15 \mathrm{jam}$. Selama itu pengrajin yang mempunyai khajat wajib bertanggung jawab kepada pengrajin lainnya yang ikut dengan drinya seperti memberi jamuan makanan dan minuman serta upah yang harus dibayar. Selain itu pengrajin yang ikut bersamanya juga bertanggung jawab menyelesaikan tugasnya dengan baik

Selaras dengan Aini, Sukestiyarno \& Waluya (2015: 116) menyatakan tanggung jawab merupakan sikap dan perilaku seseorang secara sadar dalam rangka untuk melaksanakan tugas dan kewajibannya. Pengrajin yang mempunyai khajat atau keinginan wajib bertanggung jawab atas pekerja lainnya dengan menjamu pengrajin lainnya. Pengrajin yang mempunyai khajat juga wajib memberi upah dan jaminan kesehatan selama ikut bersamanya

\section{Nilai kejujuran}

Jiwa kejujuran harus dimiliki oleh setiap orang. Begitu juga dengan masyarakat Mayong Kidul yang berprofesi sebagai pengrajin genteng. selain jiwa pengrajin masyarakat Mayong Kidul juga mempunyai jiwa kejujuran sebagai pendagang. Yekti, Oktavianti \& Ahsin (2021: 3) mengemukakan jujur merupakan perilaku yang menunjukan kebenaran dalam perkaataan maupun perbuatan dan memiliki dasar keterbukaan sehingga mejadikan kepribadian yang selalu dapat dipercaya dalam tindakannya. Setelah melakukan pengobongan atau pembakaran biasanya pengrajin menjual baranganya kepada konsumen yang membutuhkan barang tersebut. Pengrajin genteng di Mayong Kidul sudah memiliki bakul atau penadah yang menjadi pelanggan tetapnya. akan tetapi jika ada orang membutuhkan pengrajin menjualnya kepada orang tersebut selain bakul tadi. 
Pada awalnya sebelum mencapai kesepakatan pengrajin dan pembeli biasanya melakukan perundingan maslah harga yang di tawarkan. Pada kegiatan penjulan genteng, pengrajin sekaligus pedagang harus jujur kepada konsumennya. Seperti yang diungkap narasumber Budhi Ramdhani

"Yang pasti dalam membuat genteng kita jangan putus asa, jangan menyerah, kerja keras, untuk mencapai target harus disiplin, jujur dalam menjual".

Sepaham dengan penjelasan tersebut, Buono juga mengungkapkan hal yang sama

"Nilai-nilai yang muncul akibat membuat genteng adalah kerja keras, disiplin dalam bekerja, tolong-menolong sama lain, jujur dalam menjual dan menjaga kualitas barang serta tanggung jawab kepada pekerja yang lain".

Kejujuran disini yang dimaksud adalah kejujuran pengrajin yang menjadi penjual mengirimkan jumlah barang sesuai dengan yang di inginkan si pembeli. Selain itu kejujuran disini juga menjelaskan apa adanya barang yang dijual. Jika barang atau genteng di giling satu atau dua kali, pengrajin sekaligus penjual harus berkata apa adanya barang agar tidak merugikan orang lain. Karena jumlah gilingan mempengaruhi kepadatan dan kehalusan genteng.

Selaras dengan Legianai, Lestari, Raharja \& Nida (2019: 158) yang menyatakan jujur merupakan bentuk sikap dimana seseorang selalu berkata apa danya, tidak berbohong, sifat yang selalu menyatakan kebenaran dan sikap yang selalu berkata sebenarnya. kesuma 2011 kejujuran merupakan keputusan seseorang untuk mengungkapkan dalam bentuk perasaan, perkataan, dan perbuatan sesuai kenyataan yang ada tanpa menipu untuk keuntungan dirinya (Hidayah, 2019: 110).

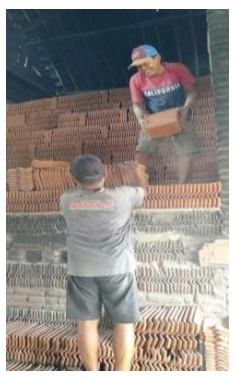

Gambar 4

Proses pemilahan genteng

Dalam proses momot atau pemilihan genteng bertujuan untuk memilah genteng yang utuh dan yang rusak hal ini dilakukan untuk menghindari pengiriman genteng yang rusak sehingga terciptanya keseimbangan antara penjual dan pembeli.

\section{SIMPULAN}

Berdsarkan peneltian yang telah dilakukan bahwa Kerajinan genteng merupakan kebudayaan masyarakat Mayong Kidul yang masih terjaga sampai sekarang. kerajinan genteng merupakan usaha turun-temurun dari generasi ke generasi. Genteng biasanya digunakan untuk atap atau payon suatu bangunan yang berfungsi melindungi dari berbagai macam kondisi alam. Adanya kerajinan genteng masyarakat Mayong Kidul mencukupi kebutuhan hidupnya. Pada praktiknya, aktivitas masyarakat dimulai dari pagi hingga sore dalam membuat kerajianan.

Pada kerajinan genteng tercermin nilai karakter disiplin yang terdapat pada aktivitas masyarakat yang memulai pekerjaannya muali pukul 7 hingga jam 4. nilai kerjasama terdapat pada aktivitas penjemuran yang bersama-sama menjemur genteng di bawah terik matahari. selain itu nilai kerja sama juga terdapat pada pembakaran di gobong tradisional yang dilakukan 2 orang yang bekerja sama menjaga api agar tetap hidup, nilai tanggung jawab dimana pada aktivitas ini membutuhkan tenaga tambahan dari pengrajin lain. Pengrajin yang mempunyai khajat atau kepereluan bertanngung jawab menjamu pengrajin lain dan memberikan hak mereka yang terdapat pada aktivitas molen dan pembakaran dan nilai jujur yang terdapat 


\section{Akhmad Iskhaq \\ Nilai-Nilai Pendidikan Karakter Dalam Budaya Genteng Desa Mayongkidul Jepara \\ JURNAL PRASASTI ILMU Volume 1 Nomor 2 hlm. 34-41}

pada aktivitas penjualan, dimana pengrajin berkata apa adanya barang yang dijual.

Karakter-karakter tersebut tertanam dalam diri pengrajin. Sehingga masyarakat tersebut menjujung nila-nilai luhur tersebut.

\section{DAFTAR PUSTAKA}

Aini, N. N., Sukestiyarno, S., \& Waluya, B. (2015). Analisis Komunikasi Matematis Dan Tanggung Jawab Pada Pembelajaran Formulate Share Listen Create Materi Segiempat. Unnes Journal of Mathematics Education Research, 4 (2) : 115-121.

Asyari, M. M., Ismaya, E. A., \& Ahsin, M. N. (2021). Nilai-Nilai Pendidikan Karakter Dalam Tradisi Apitan Masyarakat Singocandi Kudus. Wasis: Jurnal Ilmiah Pendidikan, 2(1): 34-40.

Devianty, R. 2017. Bahasa Sebagai Cermin Kebudayaan. Jurnal Tarbiyah, 24 (2): 226-245.

Hatmanto, Ari Tri. 2009. Pengujian Kualitas Genteng Pres.Skripsi. Surakarta: Pendidikan Teknik Sipil Universitas Sebelas Maret.

Hidayah, A. R., Hediyati, D., \& Setianingsih, S. W. (2019). Penanaman Nilai Kejujuran Melalui Pendidikan Karakter Pada Anak Usia Dini Dengan Teknik Modeling. Kopen: Konferensi Pendidikan Nasional, 1 (1): 109-114.

J.Moelong, Lexy. 2010. Metode Penelitian Kualitatif. Bandung: Pt. Remaja Rosda Karya

Legiani, W. H., Lestari, R. Y., Raharja, R. M., \& Nida, Q. (2019). Peran Mata Kuiah Pendidikan Karakter Dalam Menumbuhkan Karakter Jawara Mahasiswa. Untirta Civic Education Journal. 4 (2): 154-168.

Listiyani Putri, Heny. 2017. Peningkatan Karakter Kerjasama Berbasis Layanan Bimbingan Klasikal Dengan Pendekatan Metode Proyek (Skripsi). Yogyakarta: Universitas Sanata Dharma.
Ningrum, W., Ismaya, .A., \& Fajrie, N. 2020. Faktor-Faktor Pembentuk Karakter Disiplin Dan Tanggung Jawab Dalam Ekstrakurikuler Pramuka. Jurnal Prakarsa Paedogagia. 3 (1):105-117.

Purbasari, I., \& Fajrie, N. 2020. Karakter Sosial Dalam Pola Pendidikan Masyarakat Pengrajin Anyaman Bambu Desa Jepang Kudus.Prosiding Pendidikan Bela Negara Tahun 2020. 88-92

Rondiyah, A. A., Wardani, N. E., \& Saddhono, K. (2017, June). Pembelajaran Sastra Melalui Bahasa Dan Budaya Untuk Meningkatkan Pendidikan Karakter Kebangsaan Di Era Mea (Masayarakat Ekonomi Asean). In Proceedings Education And Language International Conference, 1, (1), 141-147.

Rukiyati, R., Sutarini, Y. C. N., \& Priyoyuwono, P. (2014). Penanaman Nilai Karakter Tanggung Jawab Dan Kerja Sama Terintegrasi Dalam Perkuliahan Ilmu Pendidikan. Jurnal Pendidikan Karakter, 4 (2): 213-224.

Salim, A., Salik, Y., \& Wekke, I. S. (2018). Pendidikan Karakter Dalam Masyarakat Bugis. Ijtimaiyya: Jurnal Pengembangan Masyarakat Islam, 11(1): 41-62.

Septiana, S. (2018). Sistem Sosial-Budaya Pantai: Mata Pencaharian Nelayan Dan Pengolah Ikan Di Kelurahan Panggung Kecamatan Tegal Timur Kota Tegal. Sabda: Jurnal Kajian Kebudayaan, 13(1): 83-92.

Wicaksono, D. A. (2017). Pengaruh Kedisiplinan Dalam Pendidikan Militer Tni Au Terhadap Tingkat Stress. Widya Warta: Jurnal Ilmiah Universitas Katolik Widya Mandala Madiun, 41(02): 174-186.

Yekti, N. A., Oktavianti, I., \& Ahsin, M. N. (2021). Nilai Pendidikan Karakter Dalam Dongeng Pada Buku Siswa Tema 2 Kelas 3 Untuk Siswa Sekolah Dasar. Guru Tua: Jurnal Pendidikan Dan Pembelajaran, 4(1): 1-8. 